\title{
In Vitro Propagation of Nemaguard Peach (Prunus persica 1.) Rootstock
}

El-Deeb M.D.; H. A. El-Alakmy and Shimaa M. I. Shaban

Plant Production Department, Faculty of Environmental Agricultural Sciences, Arish University, Egypt.

Received: 6/9/2018

\begin{abstract}
This study was carried out at the Plant Tissue Culture Laboratory in Faculty of Environmental Agricultural Sciences (FEAS), Arish University, Egypt during 2012 through 2015. The aim of this study was using tissue culture technique for micropropagation of peach (Prunus persica L.) plant. Nodes and shoot tips were cultured on MS, NN, WPM and B5 media containing macro and micro elements as well as vitamins, supplemented with $100 \mathrm{mgl}$ ${ }^{1}$ myo-inositol and $30 \%$ sucrose. Shoot tip cultured on the MS medium had the best combination for the establishment stage of mother plants. Multiple shoot tips were obtained on MS medium supplemented with $1.00 \mathrm{mgl}^{-1} \mathrm{BA}^{\mathrm{and}} 0.05$ $\mathrm{mgl}^{-1} \mathrm{NAA}$. The highest elongation of shoots was with $1.0 \mathrm{mgl}^{-1} \mathrm{GA}_{3}$. The highest rooting of shoots was with full strength MS medium with $2.00 \mathrm{mgl}^{-1}$ IBA. Hardening the rooted shoots was done in a greenhouse in pots containing mixture of peatmoss, vermiculite and sand at the rate1:1:1. Plantlets were successfully acclimated with $93 \%$ survive.
\end{abstract}

Keywords: Prunus persica L., Nemaguard rootstock, micropropagation, cytokinins, auxin, adenine sulphate, GA .

\section{INTRODUCTION}

Peach trees are considered as one of the most popular stone fruits, commercially produced in Mediterranean and, to a lesser extent, in continental climatic conditions. They are many promising cultivars in Egypt (El-Kosary et al., 2013). North Sinai, one of the focus points of peach cultivation, is a semi-arid region with a total precipitation of about $200 \mathrm{~mm}$ rain water /year concentrated chiefly in January, February and March (Ahmed et al., 2001). Average production in this region declined from 3.14 ton/feddan in 2010 to 1.64 ton/feddan in 2017 according to Ministry of Agriculture, A.R.E., (2017). However, tissue culture techniques created a large number of applications in the last decades, such as: massive micropropagation of commercial plants (Sulusoglu and Cavusoglu, 2013); germplasm conservation (Isac et al., 2010). Micropropagation is the process of vegetative growth and multiplication from plant tissues or seeds. It is carried out in aseptic and favorable conditions on growth media, using various plant tissue culture techniques (Nitish and Reddy, 2011).

In vitro propagation is probably the most extended application of plant tissue culture in plants (Thorpe, 2007). There are different ways that a scientist could approach firstly to obtain large numbers of plants in vitro (Boxus, 1979). Theoretically, the most efficient method would be to stimulate embryogenesis directly from callus, via embryogenesis, one could obtain thousands of plants in very little time from continuous cultures (Kochba et al., 1978). Consequently, to stimulate adventitious bud formation directly from plant organs such as leaves and stems. This could also be used to produce large numbers of plants (Skirvin, 1981). Besides, involves the stimulation of axillary bud growth. On using shoot cultures, the expansion of the dormant axis is stimulated because each of these buds would become a single shoot that could be rooted and grown to a whole plant. Clonally propagation of fruit trees would help to increase the availability and commercialization of selected genotype carrying the desired traits, production of high quality fruit trees
(Espinosa et al., 2006). Therefore, the aim of the study is to investigate the factors needed for establishing an effective protocol for propagation of Prunus persica L.

\section{MATERIALS AND METHODS}

This study was carried out in Prof. Dr. Abdelfatah Helmy Belal laboratory for Plant Tissue Culture in Faculty of Environmental Agricultural Sciences (FEAS), Arish University, El-Arish, North Sinai Governorate, Egypt, during the period from 2014 to 2016 to establish a protocol for plantlets formation from peach rootstocks (Prunus persica L.) by using micro-propagation techniques.

Active growing of new shoots was excised from Five year old trees Nemaguard cv peach rootstock from Rafah region, North Sinai Governorate, Egypt. Shoots were collected in the active growth period (March to July) and were brought to the laboratory in plastic bags. Shoot tip and node cutting were rinsed and washed thoroughly under running tap water to remove other superficial contamination with soap for $60 \mathrm{~min}$, then washed with sterilized-distilled water, placed in $500 \mathrm{ml}$ beaker containing $400 \mathrm{ml}$ sterilized-distilled water for $48 \mathrm{hrs}$ at $21 \pm 2^{\circ} \mathrm{C}$. The explants were soaked in $20 \%$ commercial bleach of Clorox solution (5.25\% $\mathrm{NaOCl}$ ) for 20 minutes, followed by washing 3-4 times in sterile-distilled water to remove all traces of the disinfectant. Sterilization steps were done under aseptic condition in Laminar Flow System using sterilized instruments. The growth parameters i.e. Number of leaves or roots / explant and shoot or root length/explant were evaluated after 6 weeks.

\section{Establishment Stage}

Medium Types: MS, W.P.M, B5 and N.N media without any hormone were examined to select the best one that induces the highest explant development (Table 1). All media were adjusted to $\mathrm{pH} 5.7$ - 5.8 using either $0.10 \mathrm{~N}$ $\mathrm{NaOH}$ or $0.10 \mathrm{~N} \mathrm{HCL}$ before agar. The medium was cooked and distributed in to glass jars $(60 \mathrm{~mm}$ diameter and $120 \mathrm{~mm}$ height) each jar contained about $50 \mathrm{ml}$ 
media. Finally jars were sterilized in autoclave at $121^{\circ} \mathrm{C}$ for $20 \mathrm{~min}$.

Explant Types: Shoot tips and one-node cuttings of Nemaguard rootstock were tested to select the best explant type which encouraged the highest development. Shoot tips were excised from terminal portion with $0.5-1.0 \mathrm{~cm}$ long containing apical meristem and 2-3 leaf primordial. One-node was prepared by dividing the rest of the shoot into $1.0-1.5 \mathrm{~cm}$ segments.

\section{Proliferation stage}

$B A$ and NAA concentrations: Different benzyl adenine (BA) concentrations i.e. 0, 0.5, 1.0, 1.5, 2.0 and $2.5 \mathrm{mgl}^{-}$ ${ }^{1}$ in combination with $0.05,0.1,0.2,0.3 \mathrm{mgl}^{-1}$ NAA were tested to investigate the most suitable concentration induced the highest multiplication.

\section{Rooting stage}

\section{Root formation phase}

Medium strength and auxin type: The elongated shoots were taken and cultured on full, half and quarter MS strengths of basal medium supplemented either with 2.0 $\mathrm{mgl}^{-1}$ indole-3-butyric acid (IBA) or $2.00 \mathrm{mgl}^{-}$ ${ }^{1}$ naphthalene acetic acid (NAA) to determine which combination of medium strength and auxin type enhanced the best root formation.

IBA concentrations: Shoots were cultured on full, half and quarter MS medium with different concentrations of IBA $\left(0,0.5,1.0,1.5\right.$ and $\left.2.0 \mathrm{mgl}^{-1}\right)$ to investigate the suitable concentration for encouraging the highest root formation.

\section{Acclimatization Stage}

Healthy and well rooted plantlets selected in vitro were taken away from the jars and washed thoroughly with running water to get rid of medium residues. Then dipped in antifungal solution (vitavax) at rate of $0.2 \%$ for 15 minutes. The roots were washed by sterilized distilled water and planted in black polyethylene pots $8 \mathrm{~cm}$ in diameter filled with three mixtures as follow: 1) 1:1:1 (v: v: v) peat moss, vermiculite, and sand; 2) 1:1:1 (v: v: v) peat moss, vermiculite, and perlite; and 3) 1:1 (v: v) peat moss, and vermiculite, then covered with white transparent bags then left under laboratory temperature till the formation of the first new leaf. Small holes were made widening these holes each week gradually and continuously for four weeks until the plantlets become suitable for transferring to bigger pots of $30 \mathrm{~cm}$ diameter and transferred to the greenhouse then transferred to field conditions.

\section{Statistical analysis}

This experiment was designed in a completely randomized design (CRD) with one or two factors and three replicates per treatment. Data were tested using the analysis of variance (ANOVA) by the General Linear Models (GLMS) procedures using SAS (SAS, 2004). Means comparisons were done using Duncans multiple range test (Duncan, 1995) at 5\% level.

Table (1): Chemical constitutes of different media i.e. MS, WPM, B5 and NN media

\begin{tabular}{|c|c|c|c|c|}
\hline \multirow{2}{*}{ Chemical components } & \multicolumn{4}{|c|}{ Culture media } \\
\hline & $\mathbf{M S}$ & WPM & B5 & $\mathbf{N N}$ \\
\hline \multicolumn{5}{|c|}{ Macro elements $\left(\mathrm{mg.l}^{-1}\right)$} \\
\hline $\mathrm{NH}_{4} \mathrm{No}_{3}$ & 1650.00 & 400.00 & - & 720 \\
\hline $\mathrm{KNo}_{3}$ & 1900.00 & - & 2500.00 & 950 \\
\hline $\mathrm{CaCl}_{2} \cdot 2 \mathrm{H}_{2} \mathrm{O}$ & 440.00 & 96.00 & 150.00 & 166 \\
\hline $\mathrm{MgSO}_{4} .7 \mathrm{H}_{2} \mathrm{O}$ & 370.00 & 370.00 & 250.00 & 185 \\
\hline $\mathrm{KH}_{2} \mathrm{PO}_{4}$ & 170.00 & 170.00 & - & 68.0 \\
\hline$\left(\mathrm{NH}_{4}\right) 2 \mathrm{SO}_{4}$ & - & 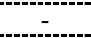 & 134.00 & - \\
\hline $\mathrm{NaH}_{2} \mathrm{Po}_{4} \mathrm{H}_{2} \mathrm{O}$ & - & - & 150.00 & - \\
\hline $\mathrm{Ca}\left(\mathrm{NO}_{3}\right)_{2} \cdot 4 \mathrm{H}_{2} \mathrm{O}$ & - & 556.00 & - & - \\
\hline $\mathrm{K}_{2} \mathrm{So} 4$ & - & 999.00 & - & - \\
\hline \multicolumn{5}{|c|}{ Micro elements $\left(\mathrm{mg} . \mathrm{I}^{-1}\right)$} \\
\hline $\mathrm{NH}_{4} \mathrm{H}_{2} \mathrm{PO}_{4}$ & - & - & - & - \\
\hline $\mathrm{H}_{3} \mathrm{BO}_{3}$ & 6.20 & 6.20 & 3.00 & 10 \\
\hline $\mathrm{MnCl}_{2} 4 \mathrm{H}_{2} \mathrm{O}$ & - & - & - & - \\
\hline $\mathrm{MnSO}_{4} \mathrm{H}_{2} \mathrm{O}$ & 16.90 & 22.30 & 10.0 & 25 \\
\hline $\mathrm{ZnSO}_{4} 7 \mathrm{H}_{2} \mathrm{O}$ & 8.60 & 8.60 & 2.00 & 10 \\
\hline $\mathrm{K} 1$ & 0.83 & - & 0.75 & - \\
\hline $\mathrm{Na}_{2} \mathrm{MoO}_{4} 2 \mathrm{H}_{2} \mathrm{O}$ & 0.25 & 0.25 & 0.25 & 0.25 \\
\hline $\mathrm{CuSO}_{4} .5 \mathrm{H}_{2} \mathrm{O}$ & 0.025 & 0.25 & 0.025 & 0.025 \\
\hline $\mathrm{CoCl}_{2} \cdot 6 \mathrm{H}_{2} \mathrm{O}$ & 0.025 & - & 2500.025 & - \\
\hline $\mathrm{FeSO}_{4} .7 \mathrm{H}_{2} \mathrm{O}$ & 27.80 & 27.80 & 27.80 & 27.6 \\
\hline $\mathrm{Na}_{2} \mathrm{EDTA}\left(2 \mathrm{H}_{2} \mathrm{O}\right)$ & 37.30 & 27.30 & 37.30 & 37.30 \\
\hline \multicolumn{5}{|c|}{ Organic components $\left(\mathrm{mg.l}^{-1}\right)$} \\
\hline Myo-Inositol & - & 100 & 100 & - \\
\hline Biotin & - & - & - & 0.05 \\
\hline Nicotinic acid & 0.50 & 0.50 & 1.00 & 5.0 \\
\hline Thiamine.HCL & 0.10 & 1.00 & 10.0 & 0.50 \\
\hline Pyridoxine.HCL & 0.50 & 0.50 & 1.00 & 0.50 \\
\hline Glycine & 2.00 & 2.0 & - & 2.00 \\
\hline Sucrose $(\mathrm{g} / \mathrm{l})$ & 30.00 & 30.00 & 30.00 & 30.00 \\
\hline
\end{tabular}




\section{RESULTS AND DISCUSSION}

Establishment stage

Effect of medium types: Results of the in vitro studies of $P$. persica L. "Nemaguard" peach rootstock presented in Figure (1) showed different responses to the types of media. The best plant length, leaves number, shoot numbers and number of leaves per shoot were occurred on MS medium (3, 23.2, 4.5 and $10.7 \mathrm{~cm})$, respectively.
Moreover the largest number of shoots was obtained on MS medium, while the lowest number on WPM and B5 media. Shoots growing on the MS medium formed the significantly longest axillary shoots while the significantly shorter shoots were obtained on the B5 medium. These results agree with results obtained by (Ahmed et al., 2003; Kassim et al., 2010).

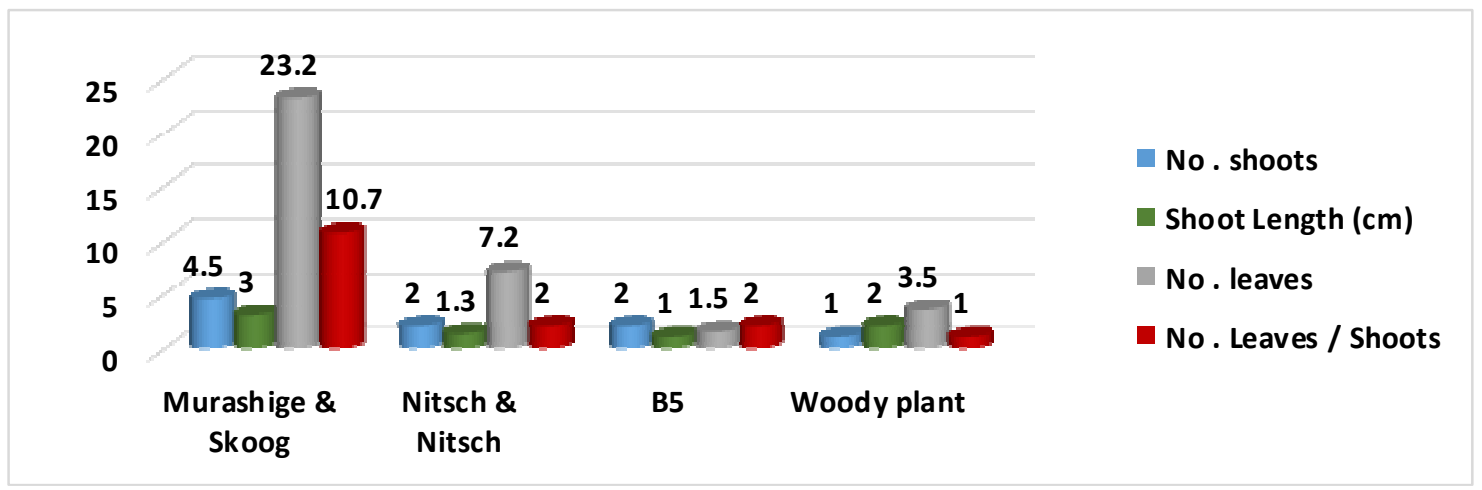

Fig (1): Effect of medium types on number of shoot, shoot length, number of leaves and number of leaves /shoots of Nemaguard peach rootstock (Prunus persica L.).

Effect of explant types: It was noticed from Figure (2) that culturing of shoot tip on MS medium increased number of shoots, shoot length, number of leaves, and number of leaves /shoots as compared with one-node cuttings explant $(2.2 \mathrm{~cm}, 11.7$ and 5.7$)$ respectively. The superiority of shoot tip with MS medium was obtained by (Xhulaj et al., 2015 and Kassaye, 2017) who found that the best shoot tip explant development was occurred on MS medium.

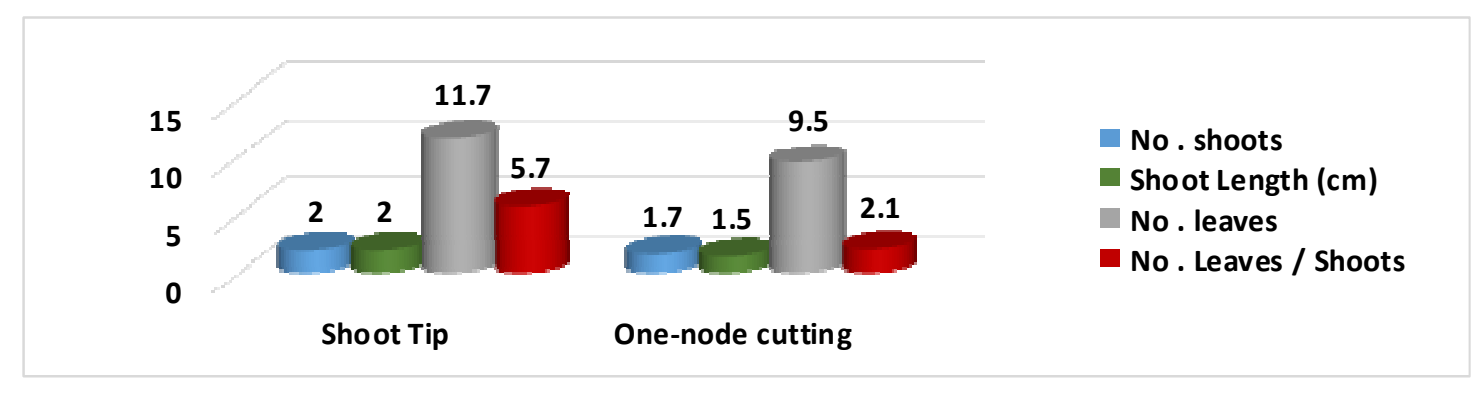

Fig (2): Effect of explant types on number of shoots, shoot length, number of leaves and number of leaves /shoots of Nemaguard peach (Prunus persica L.).

\section{Proliferation Stage}

Effect of BA and NAA concentrations

It was clear from Figure (3) that both No. of shoots (0.4) and No. of leaves (15.6) were significantly maximized when the proliferation medium supplemented with 1.0 $\mathrm{mgl}^{-1}$ BAP. However, shoot length $(6.5 \mathrm{~cm})$ was significantly increased as medium free of cytokinin was used as a control. In addition, Figure (3) also reflects the effect of different NAA concentrations on multiplication rate. Multiplication was significantly increased by using $0.05 \mathrm{mgl}^{-1} \mathrm{NAA}$ in the medium in comparison with the other concentrations .Besides, all used NAA concentrations under study enhanced significantly the
No. of leaves (10.3) in relation to the control .On the contrary, shoot length $(6.5 \mathrm{~cm})$ the highest in the control compared with the other concentrations. Referring to the results of combination of cytokinin and auxin concentrations, it is appear from Figure (3) that adding of $1.0 \mathrm{mgl}^{-1} \mathrm{BAP}$ in combination with $0.05 \mathrm{mgl}^{-1} \mathrm{NAA}$ to the culture medium succeeded in inducing the best significant No. of shoots as compared with all other combinations. Moreover, all combinations under study showed more or less significant differences as No. of leaves. However, shoot length was significantly maximized in the control as it was free of either 
cytokinin (BAP) or auxin (NAA) in comparison with all combinations under study.

It can be recommended to supplement the culture medium with $1.0 \mathrm{mgl}^{-1} \mathrm{BAP}$ in combination with $0.05 \mathrm{mgl}^{-1} \mathrm{NAA}$ for maximizing multiplication rate as compared with BA and NAA on number of shoots, shoot length and number of leaves at multiplication stage of peach $(2.3,3.8 \mathrm{~cm}$ and 21$)$, respectively. Results in Figure (3) illustrated that the best shoot number and number of leaves parameters were obtained with 1.0 $\mathrm{mgl}^{-1} \mathrm{BA}$ and $0.05 \mathrm{mgl}^{-1} \mathrm{NAA}$. These results were in harmony with the findings of Priyakumari and Sheela (2005) who found that maximum proliferation rate of "Peach Blossom" was observed on MS medium supplemented with $4 \mathrm{mgl}^{-1} \mathrm{BA}$ and $0.5 \mathrm{mgl}^{-1} \mathrm{NAA}$. Moreover, Shehata et al. (2013) mentioned that the highest average shoot length obtained with0.5 mgl-1 BA plus $0.1 \mathrm{mgl}^{-1}$ IBA on MS medium. In addition, many authors had reported that a combination of BAP or BA plus IAA on different media (LP, MS, and WPM) were required for shoot multiplication (Teixeira et al., 2004; Yang-Ning et al., 2004 and Dejampour et al., 2011).

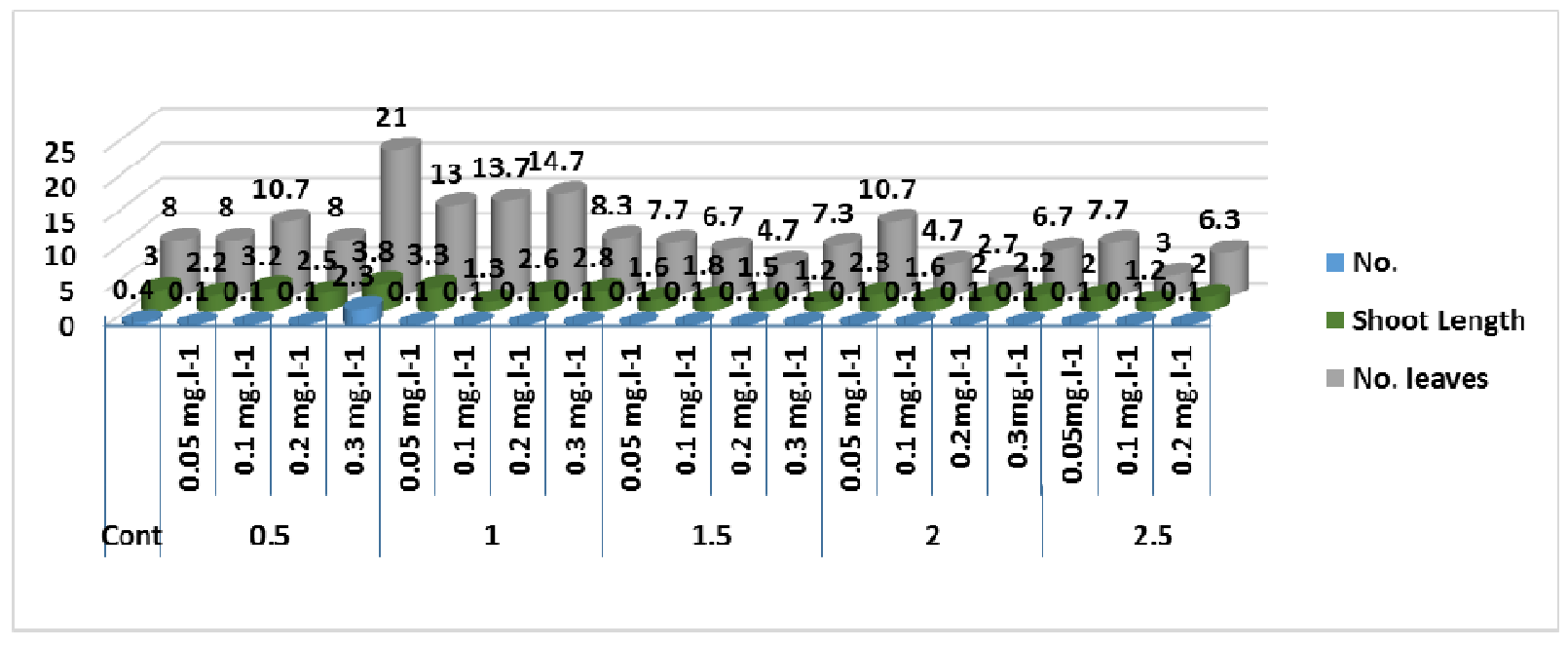

Fig (3): Interaction effect between BA and NAA on number of shoots, shoot length and number of leaves of Nemaguard peach rootstock (Prunus persica L.).

\section{Root formation phase}

Effect of medium strength: Data in Figure (4) and photo (1) showed that full MS medium strength improved all parameters under study, number of main roots, root length and plant length of Nemaguard peach rootstock (P. presica L). The data clearly show that the highest records for all number of main roots (1.1) and root length $(0.8 \mathrm{~cm})$, respectively. The finding of the current study was in consistent with the reports of Fotopoulos and Sotiropoulos (2005) who observed excellent rooting of shoots with MS medium (full strength) and (half strength).

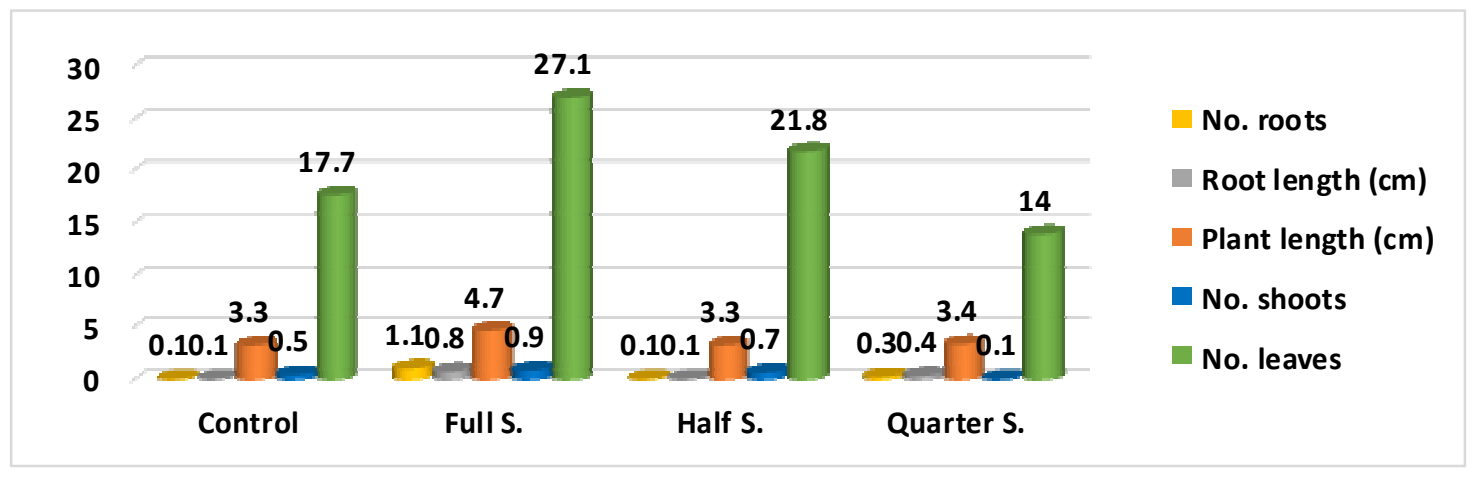

Fig (4): Effect of medium strength on number of main roots, root length, number of shoots, shoot length and number of leaves of Nemaguard peach rootstock (Prunus persica L.) 


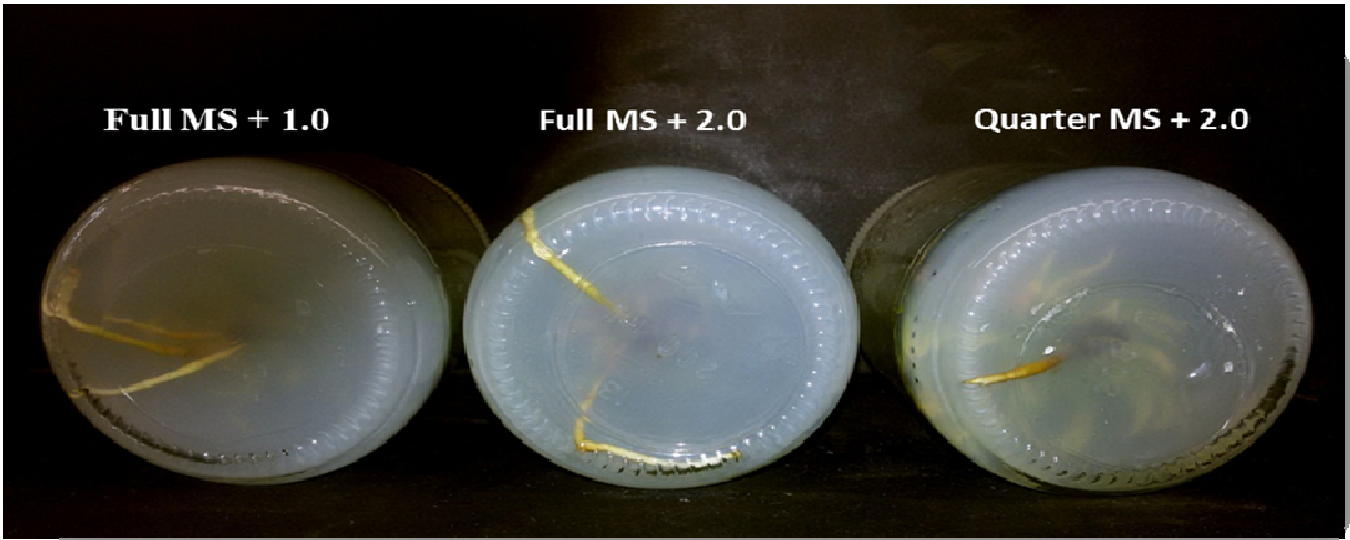

Photo (1): Effect of medium strength and IBA concentrations on rooting of Nemaguard peach rootstock (Prunus persica $\mathrm{L}$.)

Effect of auxins type: Results in Figure (5) and Photo (2) indicated that the indole-3 butyric acid (IBA) was significantly surpassed naphthalene acetic acid (NAA) in increasing all parameters under study (number of main roots, root length and plant length) of Nemaguard peach rootstock when full strength medium supplemented with $\left(2.00 \mathrm{mgl}^{-1}\right.$ IBA). The data clearly showed that the highest records were for number of main roots (2.3) and root length $(0.18$ and $6.5 \mathrm{~cm})$. This may be due to the fact that IBA produced healthier lengthy roots and hence absorbed more nutrients and water which had resulted in higher number of leaves produced by the plant. The results in general agreement with the finding of Hassan (2004) who found that IBA was the most effective auxin in enhancing root formation with $1.00 \mathrm{mgl}^{-1}$ to MS medium of apple rootstock.

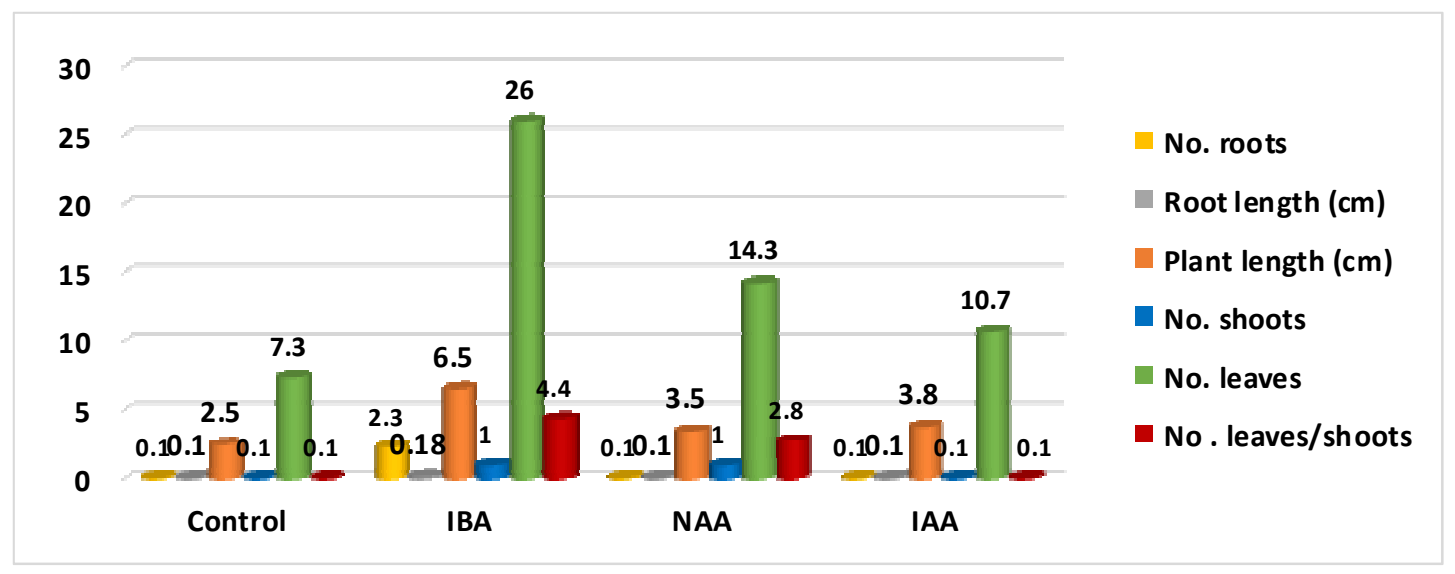

Fig (5): Effect of auxins type on number of roots, root length, number of shoots, shoot length, number of leaves and number of leaves/shoots of Nemaguard peach rootstock (P. persica L.)

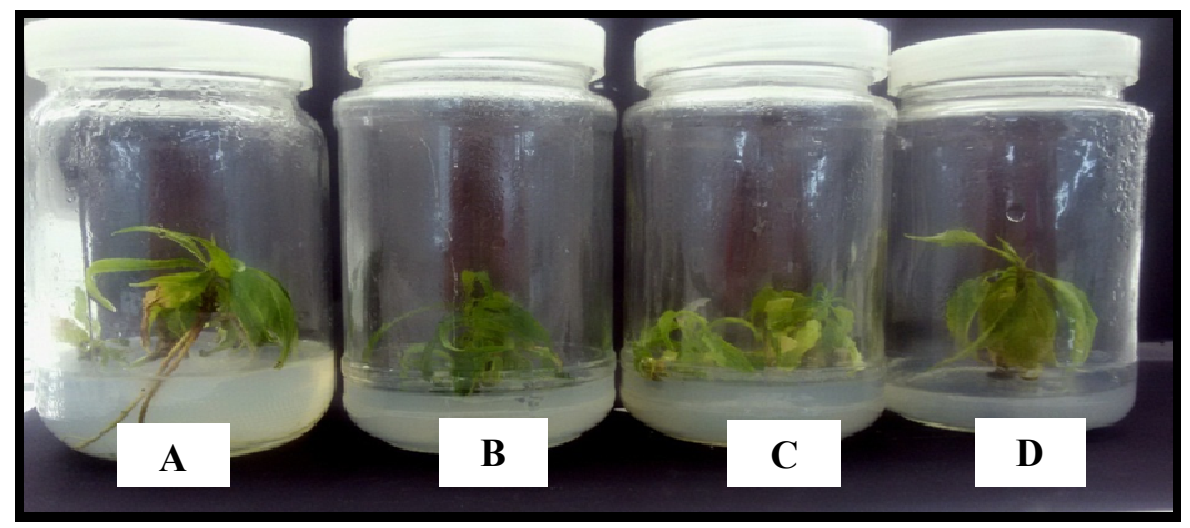

Photo (2): Effect of auxins type on root formation of Nemaguard peach rootstock (P. persica L.), Where: A=IBA $\mathrm{B}=\mathrm{NAA}, \mathrm{C}=\mathrm{IAA}$ and $\mathrm{D}=$ control (zero) 
Effect of IBA concentrations:

Data presented in Figure (6) IBA showed that induced a strong rooting response and promoted efficient root induction. The best concentration of IBA was $\left(2 \mathrm{mgl}^{-1}\right)$ on all parameters. The highest values for number of main roots, root length and plant length were 1.333, $0.916 \mathrm{~cm}, 4.333 \mathrm{~cm})$ respectively. The above results agreed with Dejampour et al. (2011). They found that IBA comparatively more effective than other two auxins (IAA and NAA). Also, many authors have reported IBA as the best auxin for rooting of peach rootstock. In addition, IBA was superior for almond Hybrid Mayor (Cos et al., 2004), peach rootstock (Al-Salihy et al., 2004) and Washington navel and Red khalili (ELHadidy, 2000), apple orine cv. (Gamage et al., 2000).
Almond cultivars (Channuntapipat et al., 2003). Similar results were obtained by Marcelo et al. (2003) who evaluated that the effect of different IBA on the In vitro rooting of Prunus rootstocks capdeboscq and GF677, and the selection vp411 and vp417 for the In vitro rooting stage, the level of $1.0 \mathrm{mgl}^{-1}$ of IBA for the rootstocks capdeboscq, Gf677 and vp411 and the level of 2-0 $\mathrm{mgl}^{-1}$ of IBA for the vp417. The same trend obtained by Priyak Umari and Sheela, (2005) who claimed that IBA $\left(2 \mathrm{mgl}^{-1}\right)$ produced the earliest rooting (7day) and the longest root $(5 \mathrm{~cm})$ in vitro. In contrast, Touqeer et al. (2003) found that the best root system was developed on half MS strength supplemented with $3.0 \mathrm{mgl}^{-1}$ IBA. Higher level of IBA $\left(4.0 \mathrm{mgl}^{-1}\right)$ induced callus.

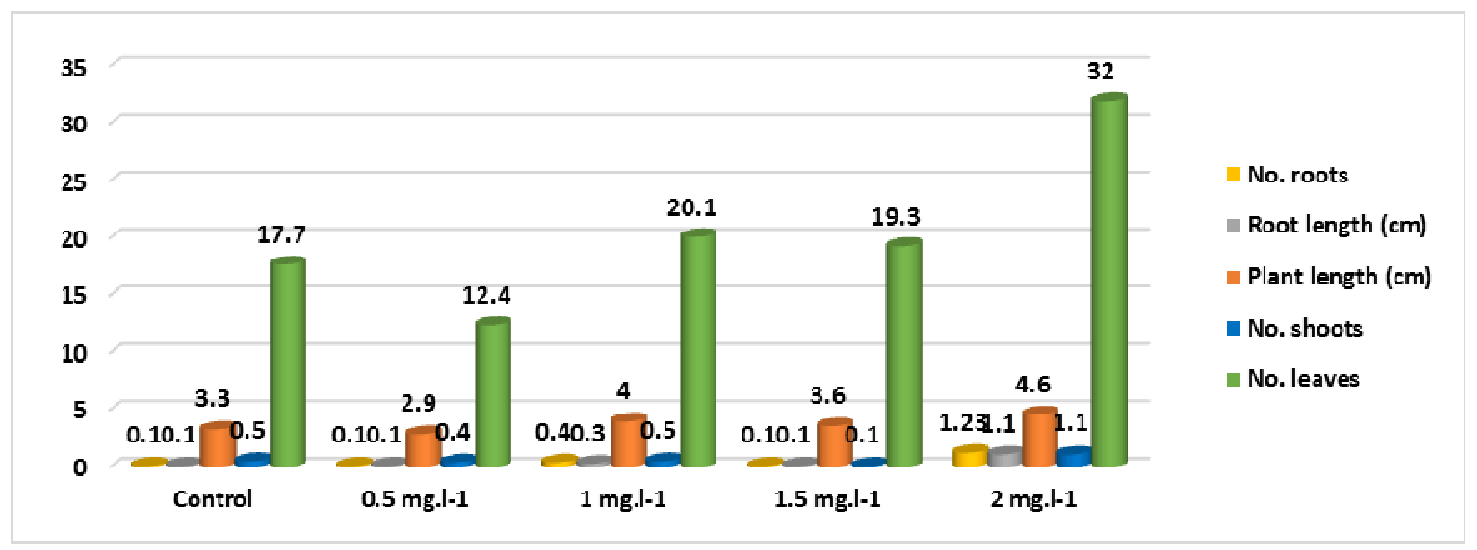

Fig (6): Effect of IBA concentrations on number of roots, root length, number of shoots, shoot length and number of leaves of peach rootstock (P. persica L.).

\section{Acclimatization stage}

In vitro rooted plantlets were acclimatized by transferring to black polyethylene pots $8 \mathrm{~cm}$ in diameter filled with three mixtures as follow: 1) $1: 1: 1(\mathrm{v}: \mathrm{v}: \mathrm{v})$ peat moss, vermiculite, and sand; 2) with 1:1:1 (v: v: v) peat moss, vermiculite, and perlite; and 3) 1:1 (v: v) peat moss, and vermiculite. The results illustrated that Plantlets were successfully acclimated with $93 \%$ survive in mixture number1, which was extremely appropriate for Acclimatization stage unlike others mixtures as shown in Figure (7). However, Kamali et al. (2001 b) mentioned that propagated plants via tissue culture of 6677 rootstock were transferred to the soil consisting of either $40 \%$ peat or $60 \%$ sand mixture. Marina et al. (2009) suggest that the improved acclimatization procedure for up 4 weeks increased the survival to $45 \%$.

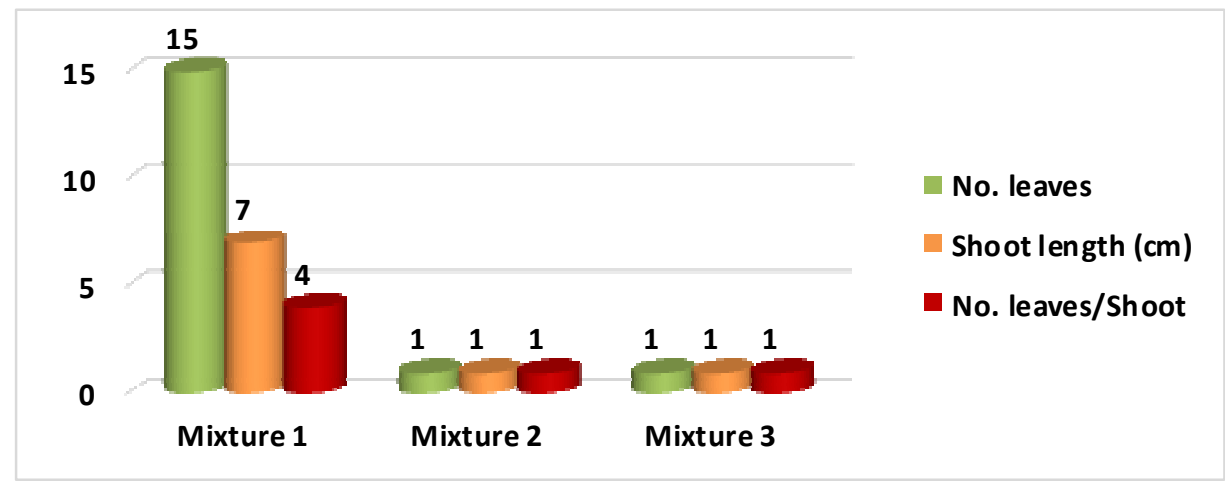

Fig (7): Effect of different mixtures for acclimatization stage on number of leaves, shoot length, and number of leaves/shoot of Nemaguard peach rootstock (P. persica L.). 

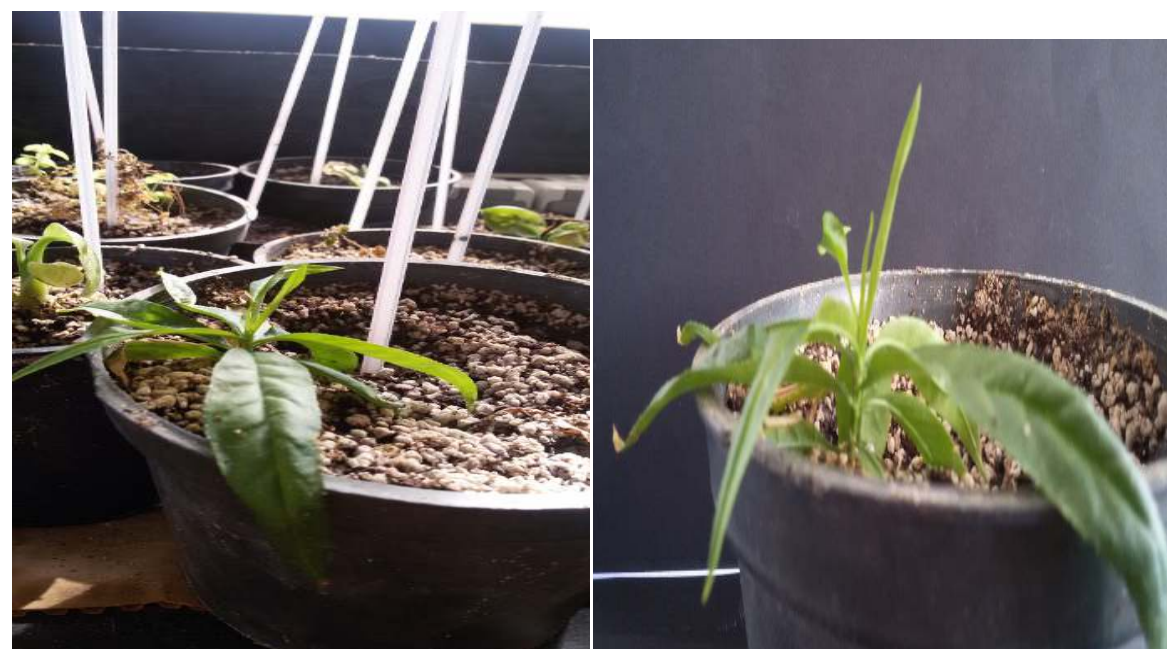

Photo (3): The best mixture 1:1:1 (v: v: v) peat moss, vermiculite, and sand for acclimatization stage of Nemaguard peach rootstock (P. persica L.).

\section{REFERENCES}

Ahmed, A.M., M.H. Kandil, H.M. EL-Shaer and H.R. Metawi, (2001). Performance of desert black goat under extensive production systems in North Sinai in Egypt. http:// om.ciheam.org/article.php?!DPDF $=160013$ 9.

Ahmed, T., H.U. Rahman, C.H.M.S. Ahmed, M.H. Laghari (2003). Effect of culture media and growth regulators on micropropagation of peach rootstock Gf677. Pak. J. Bot. 35(3):331-338.

Al-Salihy, A. W., B. Krizan, M. Klems, H. Fiserova and J. Hradilik (2004). The effect of growth regulators on the rooting of shoots of the peach rootstock Ishtara in vitro conditions. Zahradnictvi-Hortic.-Sci. 31(4):124-131.

Boxus, p. (1979). La culture de meristems de prunus. Note preliminair relative a despece. $P$. Pandora. Bull. Rech. Agron. Gembloux 6:35.

Channuntapipat, C., M. Sedgley, G. Collins and Channuntapipat-Chockpisit (2003).

Micropropagation of almond cultivars Nonpareil and Ne plus Ultra and the hybrid rootstock Titan X Nemaguard. Sci. Hortic., 98(4):473-484.

Cos, J., D. Frutos, R. García, J. Rodríguez and A. Carrillo (2004). In Vitro Rooting Study of the Peach-Almond Hybrid Mayor. Acta Hortscience 658:623-627.

Dejampour, J., I. Majidi, S. Khosravi, S. Farhadi and A. Shadmehr (2011). In vitro propagation of HS314 rootstock (Prunusamygdalus $\mathrm{x}$ P.Persica). Hortscience. 46 (6): 928-931.

Duncan, D. B. (1995). Multiple range and multiple Ftest. Biometrice, 11:1-42.

El-Hadidy, N.F. (2000). Micro-propagation of citrus by using ovule culture techniques. M. Sc.
(Hort.) Faculty of Agric. Moshtohor, Zagazig University.

El-Kosary S., M.A. Abdel-Mohsen, S. El-Merghany and A.M. Badran (2013). Enhancing the Productivity of Early Grande Peaches under Northern Sinai Conditions via Supplemental Irrigation and Organic Fertilization. J. Hortic. Sci. \& Ornam. Plants 5 (2): 77-88.

Espinosa, A.C., M. P. Paula and H. M. Charles (2006). Adventitious shoot regeneration and rooting of Prunus serotina in vitro cultures. Hort. Sci. 41(1):193-201.Skirvin, R.M. (1981). The tissue culture of fruit crops. In: Cloning Agricultural plants Via In vitro Techniques (B.V.Conger, ed) p:51-139. Chemical Rubber Company press, Boca Rotan, Florida.

Fotopoulos, S. and T.E. Sotiropoulos (2005a). In vitro propagation of the PR 204/84 peach rootstock (Prunus persica $x$ P. amygdalus): the effect of auxin type and concentration on rooting. Adv. Hortic. Sci. 19(1): 54-57.

Gamage, N., T. Nakanishi, L.H.W. Plasvan and G.J. de Klerk (2000): In vitro shoot regeneration from leaf tissue of apple cultivar. Proceedings of the International Horticultural Congress, Part 10 Applications of Biotechnology and Molecular Biology and Breeding, In Vitro Culture. Acta Hortic., 520: 291-299.

Hassan, A.A. (2004). Propagation improvement of some apple root stock and passion fruits by using tissue culture techniques. Ph. D. Hort. Fac. Agric. Moshtohor. Zagzaig Univ.

Isac V., T. Coman, L. Marinescu, M. Isac, A. Teodorescu, A. Popescu, M. Coman and C. Plopa (2010). Achievements and trends in the use of tissue culture for the mass propagation of fruit plants and germplasm preservation at the research institute for 
fruit growing, Pitesti, Romania. Rom. Biotech. Lett. 15: 92-101.

Kamali, K., E. Majidi, R. Zarghami and B. E. Ak (2001). Micropropagation of GF-677 rootstocks (Prunus amygdalus $\mathrm{x} P$. persica). Cahiers-OptionsMediterraneennes, 56: 175-177; 7 refs.

Kassaye E. W. (2017). Surface sterilization and in vitro propagation of Prunus domestica L. cv. Stanley using axillary buds as explants. J. Biotech. Res. 2017; 8:18-26.

Kassim, N .E., S.M. Abou-Rayya and E.A.M. Ali (2010). Effect of explants types and different basal nutrient media on in vitro growth of bitter almond cutting during establishment and proliferation stages. J. Amer. Sci.; 6(10):408-411.

Kochba, J., Newmann, H., and Saad, S. (1987). Stimulation of embryogenesis in Citrus ovular callus by ABA, ethiphon, CCC and alar and its suppression by $\mathrm{GA}_{3} \mathrm{Z}$. Pflanzen physiol.89:427-432.

Marcelo, R., L. K. A. de Moraes, C. Feslibino, L. Crestani, M.P. Guerra and A. L. da Silva (2003). In vitro rooting of prunus rootstocks. Rev. Bras. Frutic. 25 (2)293296.

Marina, J. A., A. Arbeloa, M. Castillo and P. Andreu (2009). Root Acclimatization of the Micropropagated Fruit Tree Rootstock 'Adafuel' (Prunusdulcis (Mill.) D.A. Webb $\times$ P. persica (L.) Batsch) Acta Hortic. 812.:403-408.

Ministry of Agriculture, A.R.E., (2017). Economic, Agriculture, Department of Agriculture Economic and Statistics.
Nitish K. and M. P. Reddy (2011). In vitro Plant Propagation: A Review. J. Forest Sci. 27(2): 61-72.

Priyakumari, I. and V. L. Sheela (2005). Micropropagation of gladiolus cv. 'Peach Blossom' through enhanced release of axillary buds. J. Tropical Agric. 43(1/2): 47-50.

SAS, (2004). SAS/STAT User, s Guide SAS Institute Inc.,Cary,N.C.

Shehata, W.F. and J. M. Al-khayri (2013).Conservation of endangered Hassawi peach (Pruns persica L.) through Micropropagation. J. Biological Sci. 13(2);75-81.

Sulusoglu, M. and A. Cavusoglu (2013). Micropropagation of cherry laurel (Prunus laurocerasus L). J. Food Agric. Environ. 11: 576-579.

Teixeira, P. de.T., A. L. da Silva, J. P. H. J. Dueroquet and M.P. Guerra (2004). In vitro multiplication of prunus spp. Rootstocks 'carelli'. Rev. Bras. De-futic. 26(2): 377379 .

Thorpe T. (2007). History of plant tissue culture. Mol. Biotech. 37: 169-180.

Touqeer, A., H. Ur. Rahman, C. M. S. Ahmed and M. H. Laghari (2003). Effect of culture media and growth regulators on micropropagation of peach rootstock GF 677. Pakistan J. Bot. 35(3): 331- 338.

Xhulaj, D., E. Kongjika and S. Xhulaj (2015). In vitro Micropropagation and Conservation of Prunus Native Stone Fruit Trees. Int. J. Green and Herbal Chem. 4(3): 403-416.

Yang-Ning, L. Sheng, W. Xiuchun and C. Ziyi (2004). Rapid Propagation of almond's rootstock. Acta. Botanica. Boreali. Occidentalia sinica. 24(2):324 -328.

\title{
الأكثار الدقيق لأصل الخوخ نيماجارد (Prunns persica L.)
}

\author{
محمد دياب الديب ، هاني عبد الله حسن العلاقمي ، شيماء محمد إبراهيم شعبان إنبان

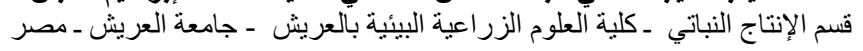

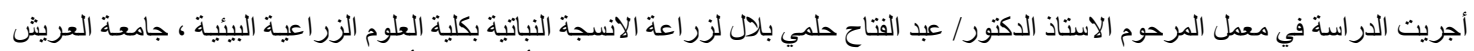

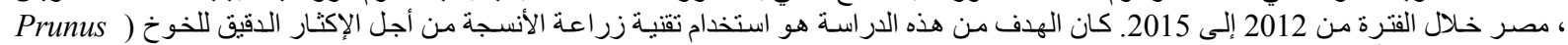

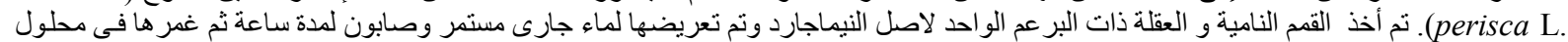

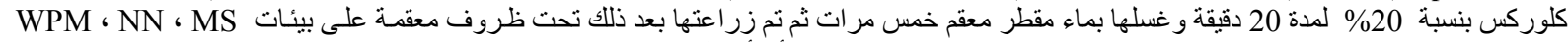

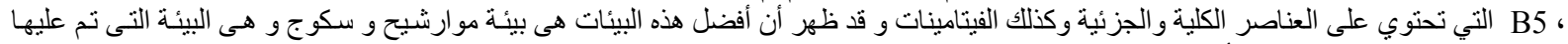

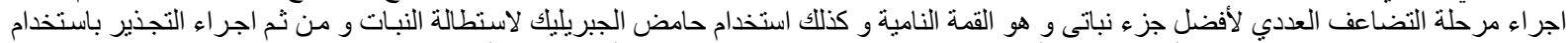
انواع مختلفة من الاوكسينات و اختيار أفضلها وكان أفضلها لركا اندول حامض البيوتريك 2 مللى ، أما مرحلة الأقلمة فقد تمت باستخدام مخلوط من البيتموس :

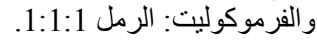

